\title{
Approaching Faculty Development Support From the Grassroots: Establishment of an Innovative, Formal, Untenured Faculty Organization
}

\author{
Ellen N. Junn \\ Ellen Kottler \\ Jacqueline K. Coffman \\ Pamella H. Oliver
}

Fred Ramirez

California State University, Fullerton

This chapter describes an innovative faculty support program designed for untenured faculty and full-time lecturers. Working closely with members of the administration, untenured faculty and full-time lecturers established and created a voluntary, formal, cross-departmental faculty organization called the ULO (Untenured Faculty and Full-Time Lecturer Organization). The ULO has formal byLaws, elected officers, and a mission that initiated activities all designed to support junior faculty and full-time lecturers within the college. Even witbin its initial year, this organization offered a significant variety of meaningful support activities with positive outcomes. The activities include formation of a Research Writing Workgroup, workshops on the tenure and promotion process, teaching brown bags, gieater opportunities for leadership development and service, reduced sense of faculty isolation (Fullan, 1993) and stress, and enhanced collegial social opportunities. Discussed bere are activities, current accomplishments, strengths, challenges, caveats, and recommendations. 
Tn recent years, many faculty development programs have added programs Ispecifically designed to support and assist new, untenured faculty (e.g., Boice \& Turner, 1989; Menges, 1996; Noonan, 1980; Pierce, 2001). Indeed, Nelsen (1980) cited research from the Association of American Colleges Project on Faculty Development showing that faculty themselves were expressing a growing interest and need for programmatic support for junior faculty beginning in the 1980s. Similarly, Stanley and Chism (1991) and Sorcinelli (1988) both provided data on the needs, concerns, and characteristics of new faculty and the implications these have for the development of meaningful faculty development programs.

However, in most instances when campuses have implemented programs of support for junior faculty, these programs are developed and constructed by administrators and faculty developers, often without the direct participation and involvement of the junior faculty themselves. Whereas programs of this nature can still benefit junior faculty enormously, a more grassroots approach is not as common. There are several reasons this might not occur. First, new junior faculty are assumed not to be as knowledgeable of the kinds of support they might need. Second, junior faculty have such limited time due to the pressures of preparing new classes and engaging in scholarship and service activities, that they might not have adequate time to devote to faculty development planning. Another reason might be that faculty development programs are often developed prior to the arrival of new faculty and hence obviate their participation.

This chapter describes the formation of an innovative, volunteer, grassroots, and formalized approach to faculty development that includes the active and full participation of junior tenure-track faculty and full-time lecturers within a college setting. These faculty work very closely with the dean's office to identify, develop, plan, and implement a variety of support programs for junior faculty. In brief, a formal, inclusive, cross-departmental junior faculty organization called the Untenured Faculty and Full-Time Lecturer Organization (ULO), complete with bylaws, elected officers, and a clear mission, was established to plan and implement activities and mobilize resources for junior faculty within the college.

There are multiple benefits to this type of formal organization.

- The ULO has greater faculty buy in, as it is perceived to be a faculty driven, grassroots organization that can communicate directly with the dean's office regarding faculty needs. 
- Because it is an open faculty organization, as opposed to a college committee, it has the advantage of being much more inclusive of all junior faculty, since committees appointed by the dean traditionally have a much smaller, representative membership drawn from all departments.

- The activities of the ULO are kept independent of the tenure and promotion process (and its often attendant stressors), although happily, parricipation in the organization may also be recognized as service to the college.

- Because it is a faculty organization with active faculty officers and members, attendance and enthusiasm for activities and events sponsored by the organization is greater, and possible fears of intimidation involving the dean's office or senior faculty are removed.

- Engaging junior faculty in the formalities of calling and conducting meetings, writing agendas and bylaws, running elections, and implementing various activities and events provides them with very valuable professional and leadership development opportunities in a relatively risk-free context.

- This model is an especially useful vehicle for socializing junior faculty particularly, in where there is a significant ratio of junior faculty to senior faculty, as experienced in our college.

- Formation of an inclusive junior faculty organization provides multiple opportunities throughout the year to develop and deepen communitybuilding support networks among faculty.

\section{BaCKGround INFORMaTION AND ESTABLISHMENT OF THE ULO}

California State University, Fullerton, has a successful and comprehensive Faculty Development Center (FDC). Because the center serves almost 2,000 faculty (i.e., untenured tenure-track, mid-career, senior, part-time faculty, and full-time lecturers), many of the programs provide support to faculty at a more general level and thus do not always address the ongoing, more specialized needs of junior faculty within smaller, disciplinary-specific college contexts.

For example, the previous FDC director did revitalize a campus-wide faculty organization fondly referred to as the UFO (Untenured Faculty Organization). Although this interdisciplinary group of UFO faculty met occasionally and provided ideas for workshops and brown bag seminars that the FDC director hosted for the group, the overall turnout at events remained small and 
the organization soon dissipated as interest in more general topics (e.g., housing issues) waned. In the end, the UFO served as more of a social gatheringwith at least one family-invited potluck evening each year, hosted at one of the junior faculty homes. Although building cross campus community is a vital activity, at that time it was more difficult to rally junior faculty to make the commitment to dedicate their time and energy to leading a campus-wide faculty organization, as many of these faculty wondered if devoting their time would be advisable, given their need to pursue their scholarly and service agendas within their own departments and colleges.

Thus, the college-based ULO began when the dean asked the associate dean to convene a luncheon for all the junior untenured faculty and full-time lecturers in the college to welcome them to the new academic year and assess their needs. During this luncheon, as the faculty broke into smaller focus groups, it became clear that junior faculty were interested in a number of crucial issues including support for research, teaching issues, negotiating tenure and promotion, and developing increased collegiality and social support.

As a result of the discussion, the associate dean and the junior faculty discussed the possibility of forming a formal, college-specific, untenured faculty organization that would provide direct and timely support to junior faculty in their scholarship, professional development, and service activities. Establishing a formal, college-based, untenured faculty and full-time lecturer organization with direct communication, credibility, and visibility with the dean's office was extremely appealing to the junior faculty. It was received with much enthusiasm and promised to serve as an excellent grassroots vehicle for identifying, developing, and implementing specific programs and activities to support faculty needs.

\section{The ULO Organization}

The organization of the ULO is defined in formal bylaws, written and approved by the general membership (the bylaws are posted on the ULO web site: http://hdcs.fullerton.edu/ULO/). The ULO was established as a collegebased organization dedicated to providing voice and support to the college's untenured faculty and full-time lecturers that pledged to work collaboratively with the dean's office in order to achieve the following goals:

- To effectively represent and promote a college-wide climate that is sensitive, representative, and fair to all untenured faculty and full-time lecturers. 
- To build a strong voice with regular, effective, formal communication and programmatic input to the dean and other relevant college committees.

- To develop and implement a variety of faculty support activities and programs for untenured faculty and full-time lecturers in collaboration with the dean's office.

- To provide support and input in the fair recruitment, hiring, retention, or promotion of untenured faculty and full-time lecturers and administrators on campus.

- To build strong, effective linkages with the university administration and with the surrounding community.

- To encourage and empower individuals in the organization to become more actively involved in important university, community, professional, and political service with the purpose of creating a more harmonious and diverse community.

- To create a social support network to build partnerships and personal friendships among the members of the organization.

The organizational and meeting structure reflects the group's philosophy of striving to maximize faculty time and efficiency. The ULO consists of three overlapping groups: general members, executive board members, and special interest group (SIG) members. General membership is open to all untenured faculty and full-time lecturers in the college. Although the group has an open enrollment policy, at the beginning of the school year, a specific invitation to join is issued to all eligible members. Currently, 39 out of 81 eligible tenuretrack and full-time lecturer faculty have officially joined as ULO members. Consistent with the goal of having no extraneous meetings, there is one general membership meeting per semester. The executive board met on a monthly basis during the first-year formation of the organization and subsequently will be meeting two times a semester. Special interest groups may meet more or less frequently, depending on their needs. The associate dean attends ULO meetings as a show of support and as a resource to assist with plans or activities, and provides the group with access to student or clerical assistance as needed.

The executive committec consists of the following officers: president, vice president, secretary, historian reporter, public relations chair, election committee chair, and all chairs of special interest groups. The duties and responsibilities of these officers are outlined in the formal bylaws. All members, tenure 
track or full-time lecturers, are eligible for serving in any position for a term of one-year term with a maximum of two years. The elections are held in the spring using a nomination slate created by consensus. The board keeps in regular contact with the associate dean and with each other through informal meetings and email.

The final area of membership consists of the special interest groups. The seven SIG chairs include: research support, teaching support, service and professional activities, tenure and promotion issues, multicultural issues, studentrelated issues, and new faculty orientation. These SIGs are formed on the basis of member interest and operate somewhat autonomously but still under the direction of the ULO board. Each of the seven special interest groups is free to identify and develop its own meeting schedule and host a variety of events. These meetings or seminars are open to all ULO members as well as to other interested faculty in the college. Electronic announcements and notification of ULO events and activities come directly from the ULO president or may be referred to the associate dean who sends the email out through the college's email distribution listing of faculty. Additionally, information is posted on the ULO web site hosted by the college.

\section{ULO ACTIVITIES AND SUCCESSES}

The ULO has been successful in achieving at least six major positive accomplishments in the following areas:

- Improving greater interdisciplinary engagement in research and writing through the implementation of a Research Writing Group;.

- Clarifying the retention, tenure and promotion process.

- Providing a forum for collegial discussions regarding teaching issues.

- Promoting leadership development.

- Enhancing community-building and social support networks.

- Using technology for more effective communication.

Each of these accomplishments will be discussed below.

\section{Research Writing Group}

Boice (1987, 1989) and others (e.g., Gray \& Birch, 2001) have written about the importance of assisting faculty with their scholarly productivity. Indeed, publication in peer-reviewed journals has become the coin of the realm for 
many institutions in making faculty tenure and promotion decisions (Bellas \& Toutkoushian, 1999). Not surprisingly, producing scholarly, peer-reviewed publications was a top priority for the ULO, and one of its first activities was to establish a Research Writing SIG under the leadership of its chair. The ULO Research Writing Group was a forum in which untenured faculty regularly shared their research interests and manuscript drafts for peer feedback in a safe, constructive, and timely manner. The group met once a month, and sometimes twice a month according to the participants' needs and requests. Meetings were set so that each participant took turns sharing rough drafts of articles, conference presentation proposals, or various scholarly items for others in the group to review. In most cases, two colleagues would serve as peer editors for each manuscript. These peer editors provided feedback and commentary on each piece of work within a specified timely frame.

An important incentive created by the Research Writing Group was that once a faculty member committed to having his or her work reviewed, if a faculty member failed to have the work ready for review by the deadline, he or she would have to buy lunch for all the members that day, or submit a monetary "donation" to each member of the group. The Research Writing Group found that this small, but simple rule acted as a powerful incentive for keeping faculty accountable to themselves and to each other in completing their work on schedule. One comment on the forced deadlines was as follows: "The research group has really helped me this year. Primarily, the forced deadlines kept me on pace. I would never have completed as much work without the support of this group of peers." These deadlines helped to emphasize the importance of consistently carving out regular time for research and writing, especially when faced with the often more immediate demands of a heavy teaching load and service activities (Boice, 1989).

Another comment included, "This group provided me with constant support and encouragement, and valuable 'tips' regarding research for me to use or modify to suit my needs. Above all, it provided me with the accountability that I needed and prefer." Another success story comes from a faculty member who said,

As a result of my involvement, an article I co-authored was presented for review to the Research Writing Group for very helpful feedback before it was submitted for publication consideration to a national journal. In addition, I used the group for feedback when I responded to a call for presenters for a national organization. The proposal was later accepted! 
The forced deadlines proved very successful for faculty productivity. There were 12 active members within the Research Writing SIG from various disciplines, and over 20 articles have been accepted for publication to date. In addition to increased productivity, the collegiality and cross-disciplinary dialogue also benefited faculty members in terms of expanding their own thinking about their research. Finally, although the group does focus primarily on research and obtaining tenure and promotion, the overarching philosophy of the group is to assist and support one another on and off campus, and, consequently the group has formed closer, collegial relationships as anorher positive outcome.

The Research Writing SIG has also been helpful in identifying needed resources and requesting the dean's office to purchase resource materials and reference books that multiple faculty in the college could share in furthering their scholarship. For example, the dean's office recently secured copies of the most recent editions of Caball's Education Directories that have now been added to the dean's library for use by the faculty.

\section{Retention, Tenure, and Promotion Issues}

For new faculty, learning about the formal, structured elements of achieving tenure can be overwhelming, intimidating, and stressful. A variety of complex university and college documents, policies, and processes govern how untenured faculty must meet and demonstrate progress toward, and attainment of, established performance criteria while developing themselves as educators, researchers, and community members both inside and outside the university. The importance of these issues is heightened as individuals prepare the critical, detailed, and sometimes highly prescriptive documentation that will be reviewed during the tenure process. Indeed, because the retention, tenure, and promotion process is multifaceted, information on the process sometimes varies between colleges on campus. Therefore, holding mectings specific to a college helps to minimize any ambiguities that might occur during discussions with colleagues in other colleges across campus.

In order to maximize clarity and alleviate some of these concerns, the ULO co-hosted with the dean's office a hands-on workshop on the tenure process specifically for faculty in the college. The Office of Faculty Affairs and Records personnel are actively involved in this process provided guidance and detailed information about required documentation, the process, related procedures, and helpful hints for the grateful and highly attentive faculty attending the workshop. In fact, one workshop participant commented, 
My experience in our last meeting was very positive and I found the meeting we had regarding RTP to be very helpful. Also, being in the presence of other faculty who are going through the same struggle helps validate and normalize our anxieties and insecurities. Thanks for all the hard work you put into this. I hope I can be more actively involved next year!

In addition to supporting faculty through the required documentation process, the ULO has publicized other related campus workshops and events that contribute to the building of teaching, research, and service activities for tenure review. For instance, the ULO highlighted and alerted faculty in the college to a variety of workshops and training sessions conducted by the campus's Faculty Development Center (e.g., research grant opportunities, microteaching seminars, web site development workshops, technical training for statistics).

\section{Teaching Issues}

Similarly, the ULO Teaching Issues SIG alerts members to other related campus workshops on teaching issues and hosts separate workshops based on topics that college faculty have expressed an interest in discussing further. As an example, the ULO invited the assistant dean of student affairs to facilitate a brown bag discussion regarding campus policies on student attendance and plagiarism and various strategies for dealing with both situations. This informal lunch was well attended and faculty dialogue was both rich and informative. Faculty appreciated the opportunity to reflect on their teaching (Schön, 1983).

\section{Leadership Development}

Junior faculty generally have limited opportunities and time to engage in sustained and meaningful leadership activities, and yet successful faculty are expected to show professional growth and development in this area as they progress in their careers. Indeed, sometimes department chairs intentionally shy away from nominating their junior faculty for leadership roles in the college for fear that these roles carry potential risks, or because of political reasons and/or extensive time commitments that would otherwise go toward successful teaching and publication of research scholarship. Fortunately, this model offers junior faculty a beneficial, yet relatively risk-free context within which to exercise their leadership skills.

More specifically, this model affords junior faculty with a number of important leadership building skills. For example, ULO faculty carrying out the 
roles, responsibilities, and duties associated with establishing and running an effective organization will enhance their leadership and administrative skills (e.g., calling and running meetings, writing agendas, working collaboratively with others, securing resources, hosting events). Second, ULO members also have the opportunity to interact formally with the dean's office and with other department chairs, thus enhancing interpersonal skills and expanding their networks. Third, active membership in ULO governance provides faculty with the opportunity to see various levels of leadership skills modeled and to test and hone their skills in a relatively risk-free and nonthreatening context. For example, as one executive member stated,

The ULO provided me with the opportunity to develop personal relationships with people in the college and to develop professional relationships as well. First of all, it offered a leadership position in the college. After assuming a position on the board, I began to interact with people from across the college through the board meetings and programs sponsored by the organization.

\section{Enhancing Community-Building and Social Support Networks}

Formation of the ULO stimulated significantly more regular and sustained interaction among the new faculty, providing for enhanced personal and professional growth. Among the myriad of larger university programs, the ULO served first to provide small group opportunities for new faculty to meet and build personal relationships. Many of the faculty had just moved to the area and were interested in meeting people, networking, and making friends. They were searching for references and information to help them settle in new communities as well as in their new faculty positions. For example, one new faculty member said, "Because of the ULO, when I walked into the elevator, I looked around and realized I could greet five of the six people there by name and even identify their departments. What a comforting feeling!" Similarly, another faculty member had the following to say:

The ULO has met my professional and personal needs on several levels: First, being new to the campus, it has been a great venue for meeting faculty within the college. It has also been enlightening to share teaching and portfolio experiences and tips informally. The sessions on student affairs and portfolio development have been educational. In fact, positive comments on ULO involvement were made by my portfolio reviewers (shows our group is valued by the college!). 
Thus, an often repeated refrain from ULO members is that the organization has made a meaningful difference in making the transition to the college and with fellow colleagues easier, much more friendly, and enjoyable.

\section{Using Technology for More Effective Communication}

In order to facilitate communication, the college hosts the ULO web site: http://hdcs.fullerton.edu/ulo/default.htm. The bylaws, meeting agendas, a list of officers, a list of current members, photo gallery, and calendar of events can be accessed on this web site. Also archived are the "ULO Updates," an electronic newsletter sent by email to the members. A final tool is "Useful Links" which connects faculty to resources and information from the library, FDC, academic affairs, and faculty affairs. The ULO president serves as the primary contact person and she posts information on a regular basis for members. This site is particularly useful for new faculty as a place to find a variety of important and timely information.

\section{Future Plans and Directions}

The ULO plans at least five activities for 2004. First, the ULO will continue to recruit new, active members with greater publicity. Second, the ULO will continue to support and build on the activities of the already successful SIGs. For example, in fall 2003, the Teaching SIG will sponsor a facilitated workshop on how women and minority faculty can cope effectively with difficult or challenging students. Third, the ULO has secured approval and funds from the dean's office to host the first joint ULO and dean's office welcome luncheon for all new tenure track and full-time lecturers this fall. Fourth, the ULO will host a meeting, much like the initial focus group, with current and new ULO members to identify new areas of interests and strengthen continuing activities. Fifth, the ULO will work collaboratively with the dean's office on the various social, community-building events that were hosted last year (e.g., faculty potluck dinners, faculty hiking trip, Monday brown bags). Enthusiasm for the organization is high and faculty continue to be actively engaged in the establishment of this organization.

\section{Challenges and Caveats}

Since junior faculty and full-time lecturers are very busy with teaching, research, and service activities, there were several challenges. For example, the greatest difficulty was in scheduling meetings and events. Due to varied faculty schedules, it became necessary to alternate the days and times when meetings 
were held. This enabled interested members to attend some, if not all, of the activities. It was extremely important to plan at least a month ahead and publicize early as well.

A second difficulty involved a slight turnover rate for some of the SIG chairs. Whereas the first slate of officer positions filled easily, as the semester progressed, a few SIG chairs voluntarily resigned when their teaching or research activities prohibited them from carrying out SIG activities effectively. However, when these few vacancies became available, the ULO president emailed an announcement to the members that the positions were now available, and, as a result, new faculty quickly became involved in these leadership positions within the organization.

Interestingly, an unforeseen difficulty came from a few department chairs who voiced some minor concerns that their faculty might turn their attention away from department service and committees to the ULO, or that permitting this group of junior faculty to organize might ferment increased distance between junior and senior faculty. Finally, some chairs wondered exactly what formal relationship the ULO had with the dean's office. To address these concerns, the associate dean invited ULO officers to present at one of the dean's council of chairs' regular meetings. At the meeting, the dean and associate dean provided a brief history and rationale for the group. Then the ULO executive board members presented the ULO mission, bylaws, an overview of events and activities, and the web site. As a result of the meeting, the chairs felt reassured and agreed that it was inspiring to see and hear from a clearly enthusiastic and well-organized group of junior faculty working together. Not only were they appreciative to learn of the organization's work, but they now support the ULO and its activities, and they easily saw how these activities would continue to strengthen the leadership potential of junior faculty.

Finally, an obvious determinant of the success of this model assumes a strong and committed leadership on the part of the faculty elected as executive board members and a mutually trusting relationship between faculty and the dean's office. In our case, we were fortunate to have a highly dedicated, wellorganized, collaborative group of executive board faculty with excellent leadership skills. However, a more novice group can be mentored and supporred by strong leadership on the part of an associate dean, some other high level administrator in the dean's office, or a senior tenured faculty member.

\section{Conclusions and Suggestions}

In the course of one school year, the ULO organization was formally established with a wide-ranging calendar of meetings, activities, and events for all 
junior faculty and full-time lecturers within a college setting. A series of programs was on a variety of topics, such as retention and promotion, teaching issues, and support for faculty research and writing. Executive board faculty were actively involved, and faculty participation and attendance at the events was strong and well received, with highly complimentary and appreciative feedback from members.

The benefits of this innovative, grassroots model of faculty development for junior faculty are many. First, it does not require significant organizational or administrative time or effort and is cost effective. Second, the programs developed are well attended and well received since the junior faculty themselves are intimately involved in identifying their needs and implementing activities. Third, this model is Hexible in that it can provide support for the faculty's multiple needs, ranging from research to teaching and more. Fourth, as Romer (1980) points out, college committees can be useful in managing faculty development, provided they are very carefully selected and charged. Expanding on this notion, our model of establishing a formal faculty organization with an infrastructure composed of an executive board, SIG members, and members at large provides even greater faculty outreach, participation, and inclusiveness. Similarly, Siegel (1980) describes empirical findings regarding faculty development programs showing that programs that are more flexible and solicit wider faculty engagement are more effective. Fifth, the ULO offers the additional benefits of enhanced leadership development and collegial networking for faculty. Sixth, it provides a safe forum for junior faculty to register formal judgments as a group regarding significant college-based issues without jeopardizing or singling out a specific faculty member (e.g., selection on a new dean or other politically loaded decisions). Seventh, programs such as these are evaluated favorably by accrediting bodies, since many accreditation bodies now specifically look for institutionalized faculty development support programs.

College deans wishing to institute a similar model of faculty development are advised to first ascertain if their junior faculty are interested in participating actively in this collaborative model. Importantly, to make this joint effort more manageable for junior faculty, the dean must ensure that another key senior level administrator, such as an associate dean, will assume primary responsibility for working closely with the group and for furnishing access to necessary clerical staff, serving in a central dissemination and communication role, offering politically asture advice where needed, identifying resources, and advocating for funding for desired activities. Finally, deans implementing this model would be wise to work closely with department chairs 
to keep them informed, comfortable, and supportive of the new faculty organization from its inception.

In sum, this grassroots approach to supporting junior faculty represents a rich, flexible, highly productive, and mutually beneficial approach to meeting the ever-changing needs of junior faculty, making their transition to the university a rich, successful, and rewarding one as highly valued members of the institution.

\section{REFERENCES}

Bellas, M. L., \& Toutkoushian, R. K. (1999). Faculty time allocations and research productivity: Gender, race, and family effects. The Review of Higher Education, 22(4), 367-390.

Boice, R. (1987). Is released time an effective component of faculty development programs? Research in Higher Education, 26(3), 31 1-326.

Boice, R. (1989). Procrastination, busyness, and bingeing. Behavior Research Therapy, $27(6), 605-611$.

Boice, R., \& Turner, J. L. (1989). The FIPSE-CSULB mentoring project for new faculty. In S. Kahn (Ed.), To improve the academy: Vol. 8. Resources for faculty, instructional, and organizational development (pp. 117-141). Stillwater, OK: New Forums Press.

Fullan, M. (1993). Change forces: Probing the dept/hs of educational reform. Bristol, PA: Farmer Press.

Gray, T., \& Birch, J. (2001). Publish, don't perish: A program to help scholars flourish. In D. Lieberman \& C. Wehlburg (Eds.), To improve the academy: Vol. 19. Resources for faculty, instructional, and organization development (pp. 268-284). Bolton, MA: Anker.

Menges, R. J. (1996). Experiences of newly hired faculty. In L. Richlin \& D. DeZure (Eds.), To improve the academy: Vol. 15. Resources for faculty, instructional, and organizational development (pp. 169-183). Bolton, MA: Anker.

Nelsen, W. C. (1980). Faculty development: Perceived needs of the 1980's. In W. C. Nelsen \& M. E. Siegel (Eds.), Effective approaches to faculty development (pp. 145-149). Washington, DC: Association of American Colleges.

Noonan, J. F. (1980). An institute on teaching and learning for new faculty. In W. C. Nelsen \& M. E. Siegel (Eds.), Effective approaches to faculty development (pp. 49-70). Washington, DC: Association of American Colleges. 
Pierce, G. (2001). Developing new faculty: An evolving program. In D. Lieberman \& C. Wehlburg (Eds.), To improve the academy: Vol. 19. Resources for faculty, instructional, and organizational development (pp. 253-267). Bolton, MA: Anker.

Romer, A. (1980). The role of a faculty committee in facilitating faculty development. In W. C. Nelsen \& M. E. Siegel (Eds.), Effective approaches to faculty development (pp. 77-83). Washington, DC: Association of American Colleges.

Schön, D. A. (1983). The reflective practitioner: How professionals think in action. New York, NY: Basic Books.

Siegel, M. E. (1980). Empirical findings on faculty development programs. In W. C. Nelsen \& M. E. Siegel (Eds.), Effective approaches to faculty development (pp. 131-144). Washington, DC: Association of American Colleges.

Sorcinelli, M. D. (1988). Satisfactions and concerns of new university teachers. In J. G. Kurfiss (Ed.), To improve the academy: Vol. 7. Resources for faculty, instructional, and organizational development (pp. 121-131). Stillwater, OK: New Forums Press.

Stanley, C. A., \& Chism, N. V. N. (1991). Selected characteristics of new faculty: Implications for faculty development. In K. J. Zahorski (Ed.), To improve the academy: Vol. 10. Resources for faculty, instructional, and organizational development (pp. 55-63). Stillwater, OK: New Forums Press.

\section{Contact:}

Ellen N. Junn

College of Human Development and Community Service

Dean's Office, EC-324

California State University, Fullerton

800 N. State College Boulevard

Fullerton, CA 92834-6868

Voice (714) 278-4365

Fax (714) 278-3314

Email cjunn@fullerton.edu

Ellen Kottler

School of Educarion, EC-190

California State University, Fullerton

800 N. State College Boulevard

Fullerton, CA 92834-6868

Voice (714) 278-5193

Email ckotsler(Affullerton.cdu 
Jacqueline K. Coffman

Department of Child and Adolescent Studies, EC-105

California State University, Fullerton

800 N. State College Boulevard

Fullerton, CA 92834-6868

Voice (714) 278-3740

Email jcoffman@fullerton.edu

Pamella H. Oliver

Department of Child and Adolescent Studies, EC-105

California State University, Fullerton

800 N. State College Boulevard

Fullerton, CA 92834-6868

Voice (714) 278-2896

Email poliver@fullerton.edu

Fred Ramirez

School of Education, EC-190

California State University, Fullerton

800 N. State College Boulevard

Fullerton, CA 92834-6868

Voice (714) 278-7643

Email framirez@fullerton.edu

Ellen N. Junn is Professor of Child and Adolescent Studies and Associate Dean in the College of Human Development and Community Service at California State University, Fullerton. She received her B.S. in experimental psychology from the University of Michigan and her M.A. and PhD in cognitive and developmental psychology from Princeton University. Her research, publications, and presentarions focus on college teaching effectiveness, faculty development issues, educational equity, public policy issues involving children and families, and children's cognition regarding social relationships. Prior to becoming Associate Dean of the college, she was the founding Director of the Faculty Development Center for the university.

Ellen Kottler is a Lecturer in the Department of Secondary Education. She reccived her B.A. in psychology from the University of Michigan, M.A. in curriculum and instruction from Eastern Michigan University, and an Fd.S. in instruction and curriculum from the University of Nevada, Las Vegas. A former teacher and curriculum specialist in the area of secondary social studies, she has preseneed at numerous conferences in social studies education and teacher education. Her areas of research interest include beginning teacher support, teacher preparation, social studies education, and children with limited English. 
Jacqueline K. Coffman is Assistant Professor of Child and Adolescent Studies at California State University, Fullerton (CSUF). She received her B.A. and M.A. from CSUF in psychology and her PhD from Claremont Graduate University in developmental psychology. Her research, presentations, and publications focus on home environment, culture, cognitive development, achievement motivation, and birth order. Departmental activities have included creation of a new course on assessing and observing development and participation in a community-based pregnant minors program and collaboration with public schools.

Pamella H. Oliver received her $\mathrm{PhD}$ in clinical psychology from the University of Southern California in 2001. Her research focuses on the influence of families on child development, with a particular emphasis on the effects of family conflict and parenting on children. She is currently an Assistant Professor in the Department of Child and Adolescent Studies at California State University, Fullerton.

Fred Ramirez is Assistant Professor of Secondary Education in the School of Education at California State University, Fullerton. He received his B.A. from San Diego State University, M.A. from Loyola Marymount, and $\mathrm{PhD}$ from Indiana University in curriculum studies. He currently oversees one of the professional development districts, and is chair of the multicultural education courses for his department. His research interests include $\mathrm{P}-12$ parental involvement, rethinking multicultural education, school reform $(\mathrm{K}-16)$, and public policy. He has presented and published in national and international conferences and journals, and in his spare time volunteers in community efforts and works with a nonprofit organization on parents and technology within urban environments. 